\title{
The Impact of Civic and Religious Social Capital on the Antisocial Attitudes of the Youth: A Multi-Level Cross-National Study
}

\author{
Željko Pavić $\mathbb{C}$
}

check for updates

Citation: Pavić, Ž. The Impact of Civic and Religious Social Capital on the Antisocial Attitudes of the Youth: A Multi-Level Cross-National Study. Societies 2021, 11, 110. https:/ / doi.org/10.3390/soc11030110

Academic Editor: Simon Susen

Received: 22 July 2021

Accepted: 6 September 2021

Published: 9 September 2021

Publisher's Note: MDPI stays neutral with regard to jurisdictional claims in published maps and institutional affiliations.

Copyright: (C) 2021 by the author. Licensee MDPI, Basel, Switzerland. This article is an open access article distributed under the terms and conditions of the Creative Commons Attribution (CC BY) license (https:/ / creativecommons.org/licenses/by/ $4.0 /)$.
Faculty of Humanities and Social Sciences, Josip Juraj Strossmayer University of Osijek, 31 000 Osijek, Croatia; zpavic@ffos.hr

\begin{abstract}
The main goal of this paper is to investigate whether some dimensions of civic and religious social capital are connected to antisocial attitudes of the youth. Based on the social capital theory and previous research, the author assumed that membership of voluntary associations as a dimension of civic social capital and attendance at religious services as a dimension of religious social capital, will be negatively correlated with antisocial attitudes of the youth. The integrated dataset of the last European Values Study and the World Values Survey waves were used as the sources of the research data. The dataset was comprised of 11,411 respondents who were younger than 25 years old from 79 countries. As hypothesized, at the individual level, attendance at religious services was negatively correlated with antisocial attitudes, whereas membership of voluntary associations was positively correlated with antisocial attitudes. At the country level, none of the hypothesized correlations were confirmed. A cross-level interaction between GDP and associational membership was found. The author explains the findings by evoking the special characteristics of religious social capital and its strength in building moral obligations and by suggesting possible differences in incentives for joining voluntary associations in the countries with different levels of economic wealth.
\end{abstract}

Keywords: social capital; religiosity; religion; antisocial attitudes; youth; multilevel study; European values study; world values survey

\section{Introduction}

Social capital consists of "some aspect of social structures and they facilitate certain actions of actors-whether persons or corporate actors-within the structure" [1] (p. 98). Alternatively, it can be defined as "features of social organizations, such as networks, norms and trust that facilitate action and cooperation for mutual benefit" [2] (p. 67). The concept is heuristically useful since it connects the notion of a purposive and rational social actor with the opportunities provided by social context and, therefore, has the potential for generalization and theoretical unification. Defined through its functions, the concept of social capital is inherently multidimensional. For instance, Tsai and Ghoshal's [3] conceptualization of social capital consists of three dimensions: structural (frequency of interaction with significant others), relational (trust) and cognitive (common understanding of social goals and expectations). Engbers, Thompson and Slaper [4] list five categories of social capital: social trust, formal membership and group participation, altruism, informal interaction and shared norms. In a simplified manner, at the micro level, social capital can be divided into attitudinal/cognitive and behavioral categories [5]. The first category is related to interpersonal and institutional trust and an individuals' sense of belonging to a community as preconditions of successful collective action or usage of resources within social networks, whereas the second one is related to direct behavioral measures, such as membership of voluntary associations, volunteering, the number of names of known neighbours, etc. It has to be borne in mind that various social capital components can be associated in complex ways, i.e., that attitudinal and behavioral dimensions of social 
capital are related and mutually reinforcing. For example, civic participation (membership of voluntary associations) can be related to generalized trust and vice versa [6].

At least some components of social capital are shown to be associated with various positive social outcomes, such as successful educational outcomes [7-9], micro-economic outcomes [10], economic growth [11,12], population health [13-15], political salience and satisfaction with democracy [16], community resilience and recovery in disaster situations [5,17]. For the current study, the most important relations are those with antisocial attitudes and behavior. Prosocial behavior of the youth is a vital prerequisite of the continuation of social norms and antisocial behavior thus presents an important research topic.

On the other hand, the accumulated evidence strongly points to the conclusion that religion exerts a strong negative influence on the various forms of antisocial attitudes and the behaviors of adolescents and youths. Previous research has shown that religiosity, especially its communal aspects, prevents substance use [18-22] and delinquency [23-26]. For instance, Mason, Schmidt and Mennis [27] found that social religiosity (attendance) and the perceived support from religious communities served as protective factors against substance use, while private religiosity (self-perceived religiosity and spirituality) did not exert such an effect, which can be interpreted as proof for the social importance of communal aspects of religion. Similarly, Bartkowski and Xiahoe [28] found that attendance at religious services was the most consistent negative predictor of drug use among youths, as opposed to the partial or even non-existing association of the other measures of religiosity (denominational affiliation, religious salience and trust in God). More directly, Cochran, Wood and Arneklev [29] established that the inverse correlation between religiosity and delinquency becomes nonexistent when psychological and physical arousal and social control are accounted for. Similar studies on the effects of religion on milder types of antisocial behavior are much less common. For instance, King and Furrow [30] determined that social capital fully mediated the influence of religiosity (religious salience, participation and activities) on the prosocial behavior measured in the study (empathic concern, perspective taking and altruism). Fondren et al. [31] found some support for the positive effect of various measures of religiosity on interpersonal warmth, candor and patience-attentiveness.

The main purpose of this paper is to investigate whether civic and religious social capital are negatively connected to antisocial attitudes. Even though it might be hypothesized that religion is changing and adapting to its ever-increasing individualized and mediatized social context [32], religious processes are still by and large social in character. As a rule, religious organizations still offer moral orientations and a shared vision of social norms, values and a sense of community. On the other hand, it could be expected that moral orientations should be embedded in social relations given that morality in itself is a social phenomenon, i.e., it deals with moral judgments within social relations and interactions. Additionally, it would be beneficial to explore the connection between religiosity, social capital and antisocial attitudes in a wider, cross-cultural context, given that most of the data about the positive outcomes of social capital on adolescents and youths have been derived from the United States [33]. As in other research topics, hypotheses and theories confirmed in one social setting do not have to fit the others. When we research the effects of religion on antisocial behavior, we should bear in mind that religion, with its strong normative commitments, might create a cultural ambiance which is more orientated towards prosocial behavior in comparison with less religious countries. It can be argued that the abundance of social capital and other resources in the religious field is not something that happens to be like that by coincidence, but that religion is a specific phenomenon which can elicit spiritual commitments that are of a high intensity and have such important consequences [34]. Therefore, I aimed to test several cross-level interactions that are theoretically interesting and have only been partially covered in previous research. For instance, Stark [35] hypothesized and empirically confirmed that the contextual effect of religiosity is very important, i.e., that there is an interaction between individual religiosity and the level of religiosity of the region based on data from the US. Namely, individual 
religiosity was a protecting factor for delinquency among the youth, but only in the regions with high religiosity.

Based on the bodies of research discussed above, I propose a number of hypotheses listed below. The rationale for the first and second hypotheses stems from the supposed protective influence of civic and religious social capital that has already been partially confirmed in previous research. The same idea is behind the third and fourth hypotheses as it can be assumed that a higher level of civic and religious social capital in a country can have an additional protective effect by creating a positive social ambiance. As for the fifth hypothesis, I wanted to test whether the influence of membership of voluntary associations might be different in countries with different levels of overall membership. Since I assumed that voluntary associations will not have a macro-effect comparable to religious associations, the hypothesis assumes no micro-macro interaction. Voluntary associations transfer social norms only latently and not manifestly, as in the case of religious associations. Consequently, in the sixth hypothesis I test Stark's [35] idea that individual religiosity is more effective in a social setting with a higher level of religiosity. In the seventh hypothesis I assumed that a higher level of societal wealth will act as a deterrent in relation to antisocial attitudes and behavior given that higher wealth creates fewer incentives to break social norms. As for the eighth hypothesis, I wanted to test whether societal wealth might be able to modify the effect of associational membership on antisocial attitudes.

Hypothesis 1 (H1). Membership of voluntary associations at the individual level is negatively correlated with antisocial attitudes.

Hypothesis 2 (H2). Attendance at religious services at the individual level is negatively correlated with antisocial attitudes.

Hypothesis 3 (H3). Membership of voluntary associations at the country level is negatively correlated with antisocial attitudes.

Hypothesis 4 (H4). Attendance at religious services at the country level is negatively correlated with antisocial attitudes.

Hypothesis 5 (H5). There is no micro-macro interaction of membership of voluntary associations.

Hypothesis 6 (H6). There is a micro-macro interaction of attendance at religious services, since the impact of attendance will be stronger in countries with a higher overall attendance.

Hypothesis 7 (H7). Higher GDP is negatively correlated with antisocial attitudes.

Hypothesis $\mathbf{8}$ (H8). There is a cross-level interaction between membership of voluntary associations and GDP.

\section{Materials and Methods}

As the source of the research data, I used the integrated European Values Study (wave 5) and World Values Survey (wave 7) dataset, downloaded from the GESIS (Leibnitz Institute for the Social Sciences) website (EVS/WVS (2021): Joint EVS/WVS 2017-2021 Dataset (Joint EVS/WVS). GESIS Data Archive, Cologne. ZA7505 Data file Version 1.1.0, https:/ / doi.org/10.4232/1.13670 (accessed on 20 May 2021)). The dataset was comprised of 79 countries from all continents with a total of 15,779 respondents who were younger than 25 years old and with sample sizes for individual countries varying from 73 (Japan) to 499 (Bolivia). However, the study sample consisted of 11,411 cases with valid answers on all study variables due to the fact that some questions were not asked in particular countries or due to refusal. The following variables/indicators from the dataset were used: 
Predictor variables (first level)

Gender (0—female, 1-male)

Father's education (from 0 -less than primary to 8 - doctoral or equivalent).

Index of the total number of individuals with a membership of voluntary associations (from 0 to 10, the list is as follows: (1) education, cultural, arts and cultural, (2) labor unions, (3) political parties, (4) ecology, (5) professional associations, (6) sports or recreation, (7) consumer groups, (8) humanitarian or charitable, (9) self-help or mutual-aid, (10) other groups.)

Religious services attendance (from 1-"never, practically never" to 8-more than once a week). Instead of denominational affiliation, I chose attendance as a measure of the communal aspect of religion due to the fact that it entails a more active participation in religious activities.

Predictor variables (second level)

GDP per capita (PPP, in USD) was gathered from the latest available publication of the World Economic Outlook, published by the International Monetary Fund (https: / / www.imf.org/en/Publications/WEO (accessed on 27 May 2021)).

As the criterion variable in the analyses, I used antisocial attitudes, i.e., the justifiability of antisocial behavior. Even though the terms "antisocial" and "prosocial" may seem controversial in that they call for further clarification on how and why something is good or bad for society, behaviors from the list that we employed in our study were directly prohibited by formal social norms. Consequently, in this framework the use of the term "antisocial" does not need further elaboration and justification. The criterion variable consisted of a summated scale of the items that measured attitudes towards the justifiability of five antisocial behaviors-(1) claiming government benefits to which you are not entitled, (2) avoiding a fare on public transport, (3) cheating on taxes, (4) someone accepting a bribe, (5) political violence. All items were measured on a scale ranging from 1 ("never justifiable") to 10 ("always justifiable"). In order to check the dimensionality of the scale, I conducted an exploratory factor analysis on a random half of the sample. The analysis revealed a one-factor solution with $52.42 \%$ of the variance explained. After that, the solution was checked on another half of the sample using a confirmatory factor analysis. The results confirmed that the model with one factor reasonably fit the data (RMSEA $=0.07$; $\mathrm{NFI}=0.97 ; \mathrm{CFI}=0.97$ ). Consequently, the items were combined in order to calculate the total results on the scale of the antisocial attitudes for each individual. Cronbach's alpha of the scale amounted to a satisfactory 0.76 . Table 1.

The description of the study variables from the sample is presented in the following

Table 1. Descriptive statistics of the study variables.

\begin{tabular}{|c|c|c|c|}
\hline Variable & Categories & $\mathbf{N}$ & Percentage \\
\hline \multirow{3}{*}{ Gender } & Female & 8107 & 51.38 \\
\hline & Male & 7669 & 48.62 \\
\hline & Unknown/missing/not asked & 5 & 0.00 \\
\hline \multirow{3}{*}{ Age } & $16-20$ yrs. & 6796 & 43.07 \\
\hline & $21-24$ yrs. & 8983 & 56.93 \\
\hline & Unknown/missing/not asked & 0 & 0.00 \\
\hline \multirow{8}{*}{ Father's education } & Less than primary or primary & 3185 & 20.19 \\
\hline & Lower or upper secondary & 6773 & 42.93 \\
\hline & Post-secondary nontertiary & 840 & 5.32 \\
\hline & Short-cycle tertiary & 809 & 5.13 \\
\hline & Bachelor or equivalent & 1293 & 8.19 \\
\hline & Master or equivalent & 1054 & 6.68 \\
\hline & Doctoral or equivalent & 195 & 1.24 \\
\hline & Unknown/missing/not asked & 1630 & 10.33 \\
\hline
\end{tabular}


Table 1. Cont.

\begin{tabular}{|c|c|c|c|}
\hline Variable & Categories & $\mathbf{N}$ & Percentage \\
\hline \multirow{5}{*}{ Membership of voluntary associations } & 0 & 5667 & 35.91 \\
\hline & $1-3$ & 6188 & 39.21 \\
\hline & $4-6$ & 1356 & 8.59 \\
\hline & 7 or more & 866 & 5.50 \\
\hline & Unknown/missing/not asked & 1702 & 10.79 \\
\hline \multirow{8}{*}{ Religious services attendance } & Never, practically never & 4126 & 26.15 \\
\hline & Less often than a year & 1921 & 12.17 \\
\hline & Once a year & 914 & 5.79 \\
\hline & $\begin{array}{c}\text { Only on special holy } \\
\text { days/Christmas/Easter days }\end{array}$ & 2814 & 17.83 \\
\hline & Once a month & 1568 & 9.94 \\
\hline & Once a week & 2474 & 15.70 \\
\hline & More than once a week & 1783 & 11.30 \\
\hline & Unknown/missing/not asked & 179 & 1.13 \\
\hline \multirow{6}{*}{ Index of antisocial attitudes } & $5-10$ & 6850 & 43.41 \\
\hline & $11-16$ & 3565 & 22.59 \\
\hline & $17-22$ & 1929 & 12.23 \\
\hline & 23-28 & 1143 & 7.24 \\
\hline & 29 and above & 834 & 5.29 \\
\hline & Unknown/missing/not asked & 1458 & 9.24 \\
\hline
\end{tabular}

Given the hierarchical nature of the data and the possibility to analyze both individuallevel and group-level effects, I conducted a series of multilevel analyses. By conducting a multilevel analysis, the researchers can allow for more reliable standard errors when estimating the impacts of the first level predictors and are able to decompose the micro (individual) and macro (country) effects on the dependent variable [36,37]. I grand-mean centered all the continuous variables in order to facilitate the interpretation of the intercepts. In all the analyses, I used the REML estimation and the variance components model. In the fourth model, I tested a model with a correlated intercept and slope, but they did not happen to be correlated. In order to simplify the presentation of the results and to maintain the focus on the main hypotheses, I did not present the results of this model in the subsequent table.

As is customary, the first model was the so-called empty (null) random intercept model, i.e., the model with no predictors, so that we could see how the variability of the criterion variable could be divided between the individual and the group level. The empty model is based on an equation which consists of intercept variability $\left(u_{o j}\right)$ and error variance $\left(\varepsilon_{i j}\right)$, as well as one fixed parameter (intercept):

$$
Y_{i j}=\gamma_{00}+u_{o j}+\varepsilon_{i j}
$$

In the second random intercept model, I added four individual-level predictors (gender, father's education, membership of voluntary associations and attendance at religious services), which led to the following equation and parameters to be estimated in the model:

$$
Y_{i j}=\gamma_{00}+\gamma_{10} \text { gender }_{i j}+\gamma_{20} \text { fath_educ }_{i j}+\gamma_{30} \text { membership } p_{i j}+\gamma_{40} \text { rel_attend } i j+\mu_{0 j}+\varepsilon_{i j}
$$

In the third model, which was a combined random intercept and random slope model, country-level membership of voluntary associations and the micro-macro interaction of the membership were added into the equation:

$$
\begin{aligned}
& Y_{i j}= \gamma_{00}+\gamma_{10 \text { gender }_{i j}}+\gamma_{20} \text { fath_educ }_{i j}+\gamma_{30} \text { membership } p_{i j}+\gamma_{40} \text { rel_attend } d_{i j}+\gamma_{01} \text { membership_country } \\
&+\gamma_{31} \text { membership }_{i j} * \text { membership_country } \\
& j
\end{aligned}
$$


In the fourth model, which was also a random intercept and random slope model, I added country-level attendance at religious services as well as the micro-macro interaction of the attendance, resulting in the following equation:

$$
\begin{aligned}
& Y_{i j}=\gamma_{00}+\gamma_{10} \text { gender }_{i j}+\gamma_{20} \text { fath_educ }_{i j}+\gamma_{30} \text { membership }{ }_{i j}+\gamma_{40} \text { rel_attend }{ }_{i j}+\gamma_{01} \text { membership_country } \\
& +\gamma_{31} \text { membership }{ }_{i j} * \text { membership_country } j+\gamma_{02} \text { rel_attend_country } y_{j}+\gamma_{41} r e l \_a t t e n d_{i j} \\
& * \text { rel_attend_country } y_{j}+u_{3 j} * \text { membership } p_{i j}+u_{4 j} * \text { rel_attend } d_{i j}+u_{0 j}
\end{aligned}
$$

Finally, in the fifth model, the GDP of the country and the interaction between GDP and membership of voluntary associations were added as additional parameters:

$$
\begin{aligned}
& Y_{i j}=\gamma_{00}+\gamma_{10} \text { gender }_{i j}+\gamma_{20} \text { fath_educ }_{i j}+\gamma_{30} \text { membership } p_{i j}+\gamma_{40} \text { rel_attend } i j+\gamma_{01} \text { membership_country } j \\
& +\gamma_{31} \text { membership } p_{i j} * \text { membership_country } y_{j}+\gamma_{02} \text { rel_attend_country } y_{j}+\gamma_{41} \text { rel_attend }{ }_{i j} \\
& * \text { rel_attend_country } y_{j}+\gamma_{03} G D P_{j}+\gamma_{32} \text { membership } i_{i j} * G D P_{j}+u_{3 j} * \text { membership } p_{i j} \\
& +u_{4 j} * \text { rel_attend_country } y_{i j}+u_{0 j}
\end{aligned}
$$

\section{Results}

\begin{tabular}{|c|c|c|c|c|c|}
\hline Parameter & Model 1 & Model 2 & Model 3 & Model 4 & Model 5 \\
\hline \multicolumn{6}{|l|}{ Structural part } \\
\hline Intercept & $12.91 * * *$ & $13.09^{* * *}$ & $13.08^{* * *}$ & $13.04 * * *$ & $12.90 * * *$ \\
\hline Gender (ref. = male) & & $-0.74^{* * *}$ & $-0.73^{* * *}$ & $-0.73^{* * *}$ & $-0.73 * * *$ \\
\hline Father's education & & -0.07 & -0.07 & -0.07 & -0.07 \\
\hline Membership of voluntary associations & & $0.49^{* * *}$ & $0.43^{* * *}$ & $0.49^{* * *}$ & $0.41^{* * *}$ \\
\hline Attendance at religious services & & $-0.12^{* * *}$ & $-0.11^{* * *}$ & $-0.12^{* * *}$ & $-0.12 * * *$ \\
\hline Membership-country level & & & 0.03 & 0.13 & 0.23 \\
\hline Micro-macro membership interaction & & & 0.01 & 0.00 & -0.03 \\
\hline Attendance-country level & & & & 0.20 & 0.57 \\
\hline Micro-macro attendance interaction & & & & -0.01 & -0.02 \\
\hline GDP per capita (in thousands) & & & & & -0.03 \\
\hline GDP-membership interaction & & & & & $-0.01 *$ \\
\hline \multicolumn{6}{|l|}{ Random part } \\
\hline Intercept variance & $9.11^{* * *}$ & $8.89^{* * *}$ & $9.09^{* * *}$ & $9.31 * * *$ & $9.16^{* * *}$ \\
\hline Residual variance & $59.88^{* * *}$ & $55.76^{* * *}$ & $55.30 * * *$ & $55.03 * * *$ & $55.02 * * *$ \\
\hline Slope variance-membership & & & $0.14^{* *}$ & $0.13^{* *}$ & $0.13^{* *}$ \\
\hline Slope variance-attendance & & & & $0.06^{*}$ & $0.06 *$ \\
\hline
\end{tabular}

The results of the empty model show that the sample intercept of antisocial attitudes amounted to 12.91 (Table 2). From the intercept and residual variances, we calculated the intra-class correlation coefficient, which amounted to 0.13 . Namely, about $13 \%$ of the variance in antisocial attitudes can be explained by the country membership and the remaining $87 \%$ by the individual differences.

Table 2. Multilevel regressions on antisocial attitudes as the criterion variable.

${ }^{*} p<0.05 ;{ }^{* *} p<0.01 ; * * * p<0.001$.

From the second model we can observe that all individual-level predictors, except father's education, were statistically significant. When all other variables were held constant, young women tended to have less tolerant attitudes toward antisocial behavior when compared to young males by 0.74 points. A one-point increase in attendance at religious services decreased the antisocial attitudes by 0.12 points. However, surprisingly, membership of voluntary associations was positively related to antisocial attitudes. To be precise, a one-point increase in membership increased antisocial attitudes by 0.49 points. The meaning of the intercept is that a female with average results on all other variables (since they were grand-mean centered) had a score of 13.09. 
From the results of the third model, we can infer that neither country-level membership of voluntary associations nor the micro-macro interaction of membership were statistically significant predictors. The same goes for the fourth model, wherein neither attendance at religious services at the country level nor the corresponding micro-macro interaction were statistically significant.

Finally, in the fifth model, the cross-level interaction between membership of voluntary associations and GDP per capita proved to be statistically significant, whereas the coefficients for the individual-level predictors stayed about the same. It can be noted that the interaction coefficient was negative, meaning that the coefficient of membership of voluntary associations became smaller as GDP per capita rose. To be more precise, it can be calculated that the effect of the membership became positive at a GDP level per capita of about USD 57,000 (approximately the GDPs per capita of Austria and Germany). I can also point out that GDP per capita as such was not connected to antisocial attitudes, but it moderated the relationship between the membership and antisocial attitudes. It is also important to highlight that a significant variation in membership and attendance slopes remained even after all variables were entered into the model, i.e., the countries from the sample still significantly differed in terms of the influence of these measures of civic and religious social capital on antisocial attitudes.

In Table 3, the parameters of the model fit are shown. Given that the models were nested, I tested the model fit with the differences of -2 log-likelihood parameters, since such differences followed a chi-square distribution with degrees of freedom equal to the difference in the number of parameters estimated in the models [38]. According to the fit indices, the second model provided the best fit for the research data, i.e., the additional predictors did not bring an improved explanatory power, given that the third, fourth and the fifth model used more parameters.

Table 3. Parameters of model fit.

\begin{tabular}{cccccc}
\hline Parameter & Model 1 & Model 2 & Model 3 & Model 4 & Model 5 \\
\hline -2 Restricted Log Likelihood & $99,494.43$ & $78,508.99$ & $78,514.60$ & $78,520.06$ & $78,526.09$ \\
\hline Akaike's Information Criterion (AIC) & $99,498.43$ & $78,512.99$ & $78,518.60$ & $78,524.06$ & $78,530.09$ \\
\hline Hurvich and Tsai's Criterion (AICC) & $99,498.43$ & $78,512.99$ & $78,518.60$ & $78,524.06$ & $78,530.09$ \\
\hline Bozdogan's Criterion (CAIC) & $99,515.57$ & $78,529.68$ & $78,535.28$ & $78,540.74$ & $78,546.77$ \\
\hline Schwarz's Bayesian Criterion (BIC) & $99,513.57$ & $78,527.68$ & $78,533.28$ & $78,538.74$ & $78,544.77$ \\
\hline
\end{tabular}

\section{Discussion}

The most important result of the study presented in this paper is somewhat surprising. Even though possible negative effects of social capital for particular organizations and the society as a whole have been frequently noted [39-42], the study finding that membership of voluntary associations could have an overall detrimental effect on the antisocial attitudes of the youth was not expected and it refuted my first hypothesis. Any explanation of the abovementioned finding must explain why the conventional wisdom that emphasizes the positive effects of social capital on the youth might not be true in some cases. The explanation must incorporate two additional specific findings as well. First, it has to explain why the effect of religious services on antisocial attitudes is negative, as predicted by my second hypothesis. Second, it has to explain the interaction between GDP per capita and membership of voluntary associations. Taken together, the explanation must take into account the finding that the effect of social capital might be different in different associations and in different countries, depending on the nature of such associations and on some country characteristics that are caused by economic wealth, or are at least correlated with it.

In a search for plausible explanations, we need to be very careful and to painstakingly differentiate between several types of antisocial and prosocial attitudes and behaviors. 
Namely, strong positive impacts of social capital might be reserved to the more serious types of antisocial behavior, such as substance abuse or delinquency. Such behavior is widely socially condemned and might be particularly susceptible to social influence. On the other hand, milder versions of antisocial attitudes and behaviors, such as those measured in the current study, might not be affected by the social capital of the youth. Even though milder antisocial attitudes and behaviors have been much less researched, some studies have pointed in the direction of such a conclusion. For instance, Barton, Thorpe and Dafur [33] found almost no connection between measures of the within-family social capital (frequency of interaction) and religious social capital (religious self-identification and active membership of religious communities) and prosocial behavior such as kindness, consideration for others and voluntarily helping others.

Second, the positive effect of religious attendance might point to the fact that religious associations are somewhat different from other associations. They are characterized by strongly shared worldviews and cross-generational ties that can be very effective in transmitting social values and norms. Religious groups are very often abundant with communitarian feelings and social commitments, whereas for other voluntary associations this is often not the case [43]. Smith [34] posits that religion has great potential to build social capital since it fosters both intragenerational and intergenerational networks between the members of religious organizations which can strengthen moral commitments by providing role models or influencing the plausibility structures of the moral commitments. Some studies have shown that the religiosity of peers prevents antisocial behavior of the youth [44]. Youths who are not members of religious organizations often lack such ties and thus are more easily influenced by the peers who exhibit antisocial behavior. Furthermore, Smith points to the fact that religious organizations demonstrate more intergenerational network closure which may have a similar effect on building prosocial behavior, mainly by providing informational supervision over the youth and that religious organizations provide extra-community links which can enhance various useful competencies.

All religions, to some degree, have a social ethic that emphasizes prosocial behavior, i.e., respect for social norms and the public good. For other types of horizontal associations this might not always be the case. The list of association types used in WVS and EVS does not tell us whether such associations convey universalistic or particularistic attitudes and behaviors. As Portes and Sensenbrenner [39] have noted, social capital that arises from bounded solidarity and enforceable trust is often part of the communities who are discriminated against and who develop an inimical stance towards outside society. Besides the other negative consequences that Portes and Sensenbrenner mention, such as the costs of community solidarity and the constraints on freedom, this situation obviously leads to a particularistic outlook that should not be opposed, for instance, collecting undeserved social benefits or free riding on public transportation. The large multinational sample used in the current study allowed for a more general test and a confirmation of the above mentioned hypothesized differential effects of civic and religious social capital on the antisocial attitudes of the youth. As noted earlier, the bulk of research on the impact of religious social capital on antisocial attitudes and behavior has come from the United States and this impact has not been reliably confirmed elsewhere, i.e., in the social settings in which religion might have different social roles than in the United States.

The cross-level interaction between a country's economic wealth and membership of voluntary associations might be explained in two ways. First, it is possible that such associations transmit antisocial values in countries where such values are more often present. Here I evoke Portes' [45] classification of the possible determinants of the negative effects of social capital. Namely, Portes lists (a) excessive claims on group members, (b) exclusion of outsiders, (c) restrictions on freedom and (d) downward leveling norms (emerging antisocial norms). The fourth determinant seems to be applicable to the problem at hand. Namely, in a situation where antisocial attitudes and behaviors are already present to a degree, they can be further propagated through cohesive social networks. Such an explanation is reminiscent of the difference between bonding and bridging social capital [46], where 
the former tends to transfer more particularistic norms within the network. Indeed, some research [47] has shown that associational membership can exert a negative impact on political tolerance in countries such as those of Eastern and Central Europe, where highly homogeneous associations build only on particularized trust. Lower levels of economic wealth may be a proxy indicator of the weaker states in which voluntary associations do not convey impartial universalistic rules, but serve as vehicles for particularistic interests [48].

Even though there is a negative correlation between GDP per capita and the support for antisocial behaviors, in all countries the level of support is quite low. To illustrate the point, the highest level of support exists in Philippines, but even there it is only 22.84 on a 5 to 50 scale. Therefore, such an idea would be contingent upon a condition that there is high level of socially desirable answers, i.e., that the support for antisocial behavior is much higher than that stated in this and other surveys. The other explanation would rest upon the idea of some kind of selection effect. For instance, it might be possible that voluntary associations in countries with a lower level of economic wealth somehow attract persons who support antisocial behavior, i.e., who try to achieve their goals in a manner which is not respectful to social norms. In other words, voluntary associations might be a wheel for social success by any means available in a situation where it is harder to achieve success/wealth by legitimate means. Alternatively, voluntary associations in countries with lower economic wealth might be more often present in urban areas, which in turn might be more affected by anomic processes, i.e., on average might show more support for antisocial values.

The other possible explanation that connects membership of voluntary associations with the country-level membership does not seem very plausible to me. Namely, similar cross-level interactions have already been established in health research and typically reveal that high-trusting social settings can harm low-trusting individuals and vice-versa $[49,50]$. The logical explanation for such findings would be the social exclusion that happens to the individuals whose trust habits are incongruent with those of their social surroundings. However, we cannot easily extend this idea to the membership of voluntary associations, i.e., it would be an immense task to theoretically demonstrate that, for some reason, high-membership individuals exhibit more antisocial attitudes and behaviors in lowmembership (or high-membership) countries.

To sum up, most of the above-mentioned studies are not comprised of a large number of countries $[40,42,47,48]$ from all over the world [50], and/or they tested and theorized the negative effects of social capital in specific social contexts, such as immigrant communities and their relation to the wider society $[39,45]$. The findings of the current study add to the previous studies by detecting the negative effects of social capital in a sample comprised of a large number of countries and by pointing out to the possible role of economic wealth in this process. This opens a possible new direction for future research which should investigate whether economic wealth has a direct influence on the individual cost-benefit calculation with relation to social norms.

\section{Conclusions}

Overall, the results of the study presented in this paper cast serious doubt on the idea that social capital is the main source of public virtues and civic orientation. Even though this idea should not be abandoned as such, it should be qualified by a reaffirmation of the importance of the effect of both individual and contextual interaction. To put it succinctly, social capital may only work in some situations and for some people and we should not be surprised to find its negative and dysfunctional effects. Future studies in different areas where social capital might be presumed to be operational should investigate under which conditions the same structural components of social capital may lead to completely opposite results. The study results also warn us that voluntary associations are comprised of a very wide range of different associations which may have different impacts on various attitudes and behaviors. Future research should try to differentiate between them and to theoretically explain their possible different impacts. 
However, this study is not without limitations. The measurement of civic and religious social capital was quite simple and limited and was mostly conditioned upon the variables which were available in the dataset and the need to keep the regression models interpretable. Taking into account the complexity and multidimensionality of the concepts of social capital and religiosity, future studies with different operationalizations of the concepts are highly warranted.

Funding: This research received no external funding.

Institutional Review Board Statement: Ethical review and approval were waived for this study, due to the fact that the study uses no primary data collected on humans.

Data Availability Statement: Publicly available datasets were analyzed in this study. This data can be found here: https:/ / doi.org/10.4232/1.13670 (accessed on 20 May 2021).

Conflicts of Interest: The authors declare no conflict of interest.

\section{References}

1. Coleman, J.S. Social Capital in the Creation of Human Capital. Am. J. Sociol. 1988, 94, 95-120. [CrossRef]

2. Putnam, R.D. Bowling Alone: America's Declining Social Capital. Cult. Polit. 2000, 6, 223-234. [CrossRef]

3. Tsai, W.; Ghoshal, S. Social Capital and Value Creation: The Role of Intrafirm Networks. Acad. Manag. J. 1998, 41, 464-476. [CrossRef]

4. $\quad$ Engbers, T.A.; Thompson, M.F.; Slaper, T.F. Theory and Measurement in Social Capital Research. Soc. Indic. Res. 2017, 132, 537-558. [CrossRef]

5. Aldrich, D.P.; Meyer, M.A. Social Capital and Community Resilience. Am. Behav. Sci. 2015, 59, 254-269. [CrossRef]

6. Pavić, Ž.; Šundalić, A. A Comparison of Online and Offline Social Participation Impacts on Generalized Trust. Ital. Sociol. Rev. 2016, 6, 185. [CrossRef]

7. Coleman, J.S. Families and Schools. Educ. Res. 1987, 16, 32-38. [CrossRef]

8. Pavić, Ž.; Đukić, M. Cultural Capital and Educational Outcomes in Croatia: A Contextual Approach. Sociológia 2016, 48, 601-621.

9. Nygård, O.; Behtoui, A. Access to Social Capital and Educational Returns for Children of Immigrants: Evidence from Three Swedish Studies. Nord. J. Migr. Res. 2020, 10, 50-66. [CrossRef]

10. Silkoset, R. Negative and Positive Effects of Social Capital on Co-Located Firms' Withholding Efforts. Eur. J. Mark. 2013, 47, 174-197. [CrossRef]

11. Boulila, G.; Bousrih, L.; Trabelsi, M. Social Capital and Economic Growth: Empirical Investigations on the Transmission Channels. Int. Econ. J. 2008, 22, 399-417. [CrossRef]

12. Muringani, J.; Fitjar, R.D.; Rodríguez-Pose, A. Social Capital and Economic Growth in the Regions of Europe. Environ. Plan. A 2021. [CrossRef]

13. Folland, S. Does "Community Social Capital” Contribute to Population Health? Soc. Sci. Med. 2007, 64, 2342-2354. [CrossRef]

14. Nieminen, T.; Prättälä, R.; Martelin, T.; Härkänen, T.; Hyypä, M.A.; Alanen, E.; Koskinen, S. Social Capital, Health Behaviours and Health: A Population-Based Associational Study. BMC Public Health 2013, 13, 613. [CrossRef]

15. Miyamoto, K.; Iwakuma, M.; Nakayama, T. Social Capital and Health: Implication for Health Promotion by Lay Citizens in Japan. Glob. Health Promot. 2015, 22, 5-19. [CrossRef]

16. Van Deth, J.W. Participation in Voluntary Associations: Dark Shades in a Sunny World? Am. Behav. Sci. 2010, 53, 640-656. [CrossRef]

17. Delilah Roque, A.; Pijawka, D.; Wutich, A. The Role of Social Capital in Resiliency: Disaster Recovery in Puerto Rico. Risk, Hazards Cris. Public Policy 2020, 11, 204-235. [CrossRef]

18. Miller, L.; Davies, M.; Greenwald, S. Religiosity and Substance Use and Abuse among Adolescents in the National Comorbidity Survey. J. Am. Acad. Child Adolesc. Psychiatry 2000, 39, 1190-1197. [CrossRef] [PubMed]

19. Yeung, J.W.K.; Chan, Y.C.; Lee, B.L.K. Youth Religiosity and Substance Use: A Meta-Analysis from 1995 to 2007. Psychol. Rep. 2009, 105, 255-266. [CrossRef] [PubMed]

20. Allen, T.M.; Lo, C.C. Religiosity, Spirituality, and Substance Abuse. J. Drug Issues 2010, 40, 433-459. [CrossRef]

21. Ford, J.A.; Hill, T.D. Religiosity and Adolescent Substance Use: Evidence from the National Survey on Drug Use and Health. Subst. Use Misuse 2012, 47, 787-798. [CrossRef]

22. Gomes, F.C.; de Andrade, A.G.; Izbicki, R.; Almeida, A.M.; de Oliveira, L.G. Religion as a Protective Factor against Drug Use among Brazilian University Students: A National Survey. Rev. Bras. Psiquiatr. 2013, 35, 29-37. [CrossRef]

23. Desmond, S.A.; Soper, S.E.; Purpura, D.J.; Smith, E. Religiosity, Moral Beliefs, and Delinquency: Does the Effect of Religiosity on Delinquency Depend on Moral Beliefs? Sociol. Spectr. 2009, 29, 51-71. [CrossRef]

24. Desmond, S.A.; Soper, S.E.; Kraus, R. Religiosity, Peers, and Delinquency: Does Religiosity Reduce the Effect of Peers on Delinquency? Sociol. Spectr. 2011, 31, 665-694. [CrossRef] 
25. Adamczyk, A.; Freilich, J.D.; Kim, C. Religion and Crime: A Systematic Review and Assessment of Next Steps. Sociol. Relig. A Q. Rev. 2017, 78, 192-232. [CrossRef]

26. Sumter, M.; Wood, F.; Whitaker, I.; Berger-Hill, D. Religion and Crime Studies: Assessing What Has Been Learned. Religions 2018, 9, 193. [CrossRef]

27. Mason, M.J.; Schmidt, C.; Mennis, J. Dimensions of Religiosity and Access to Religious Social Capital: Correlates with Substance Use among Urban Adolescents. J. Prim. Prev. 2012, 33, 229-237. [CrossRef]

28. Bartkowski, J.P.; Xu, X. Religiosity and Teen Drug Use Reconsidered. A Social Capital Perspective. Am. J. Prev. Med. 2007, 32, S182-S194. [CrossRef]

29. Cochran, J.K.; Wood, P.B.; Arneklev, B.J. Is the Religiosity-Delinquency Relationship Spurious? A Test of Arousal and Social Control Theories. J. Res. Crime Delinq. 1994, 31, 92-123. [CrossRef]

30. Ebstyne King, P.; Furrow, J.L. Religion as a Resource for Positive Youth Development: Religion, Social Capital, and Moral Outcomes. Psycholog. Relig. Spiritual. 2008, S, 34-49. [CrossRef]

31. Fondren, K.M.; Bartkowski, J.P.; Xu, X.; Levin, M.L. Are Religious Teens Nice Kids? Faith and Congeniality among American Adolescents. Religions 2018, 9, 328. [CrossRef]

32. Pavić, Ž. Mediatization of Religion in the Context of Religious Transformation. Nov. Prisut. 2016, 14, 283-297. [CrossRef]

33. Barton, H.; Thorpe, J.; Dufur, M. Social Capital and Prosocial Behavior among German Children. Soc. Sci. 2020, 9, 215. [CrossRef]

34. Smith, C. Theorizing Religious Effects Among American Adolescents. J. Sci. Study Relig. 2003, 42, 17-30. [CrossRef]

35. Stark, R. Religion as Context: Hellfire and Delinquency One More Time. Sociol. Relig. A Q. Rev. 1996, 57, 163-173. [CrossRef]

36. Bickel, R. Multilevel Analysis for Applied Research: It's Just Regression; Guilford Press: New York, NY, USA, 2007.

37. Hox, J. Multilevel Analysis: Techniques and Applications; Lawrence Erlbaum Associates: Mahwah, NJ, USA, 2002.

38. Heck, R.H.; Thomas, S.L.; Tabata, L.N. Multilevel and Longitudinal Modeling with IBM SPSS; Routledge: New York, NJ, USA, 2010.

39. Portes, A.; Sensenbrenner, J. Embeddedness and Immigration: Notes on the Social Determinants of Economic Action. In The Sociology of Economic Life, 3rd ed.; Routledge: London, UK, 2018; pp. 93-115. [CrossRef]

40. Pillai, K.G.; Hodgkinson, G.P.; Kalyanaram, G.; Nair, S.R. The Negative Effects of Social Capital in Organizations: A Review and Extension. Int. J. Manag. Rev. 2017, 19, 97-124. [CrossRef]

41. Villalonga-Olives, E.; Kawachi, I. The Dark Side of Social Capital: A Systematic Review of the Negative Health Effects of Social Capital. Soc. Sci. Med. 2017, 194, 105-127. [CrossRef]

42. De Vaan, M.; Frenken, K.; Boschma, R. The Downside of Social Capital in New Industry Creation. Econ. Geogr. 2019, 95, 315-340. [CrossRef]

43. Coleman, J.A. Religious Social Capital: Its Nature, Social Location, and Limits. In Religion as Social Capital: Producing the Common Good; Smidt, C., Ed.; Baylor University Press: Waco, TX, USA, 2003; pp. 33-47.

44. French, D.C.; Purwono, U.; Rodkin, P.C. Religiosity of Adolescents and Their Friends and Network Associates: Homophily and Associations With Antisocial Behavior. J. Res. Adolesc. 2012, 22, 326-332. [CrossRef]

45. Portes, A. Social Capital: Its Origins and Applications in Modern Sociology. Knowl. Soc. Cap. 2009, 24, 43-68. [CrossRef]

46. Putnam, R.D. Bowling Alone: The Collapse and Revival of American Community; Simon \& Schuster: New York, NY, USA, 2000.

47. Iglič, H. Voluntary Associations and Tolerance: An Ambiguous Relationship. Am. Behav. Sci. 2010, 53, 717-736. [CrossRef]

48. Portes, A.; Vickstrom, E. Diversity, Social Capital, and Cohesion. Annu. Rev. Sociol. 2011, 37, 461-479. [CrossRef]

49. Subramanian, S.V.; Kim, D.J.; Kawachi, I. Social Trust and Self-Rated Health in US Communities: A Multilevel Analysis. J. Urban Health 2002, 79 (Suppl. 1), S21-S34. [CrossRef] [PubMed]

50. Campos-Matos, I.; Subramanian, S.V.; Kawachi, I. The "dark Side" of Social Capital: Trust and Self-Rated Health in European Countries. Eur. J. Public Health 2016, 26, 90-95. [CrossRef] [PubMed] 